\title{
Фітосанітарний стан зелених насаджень у міському озелененні Луцька
}

\section{Марія Шепелюк, Юлія Рибак}

Східноєвропейський національний університет імені Лесі Українки, Луцьк, Україна Адреса для листування: shepelyk.maria@gmail.com

Отримано: 18.04.19; прийнято до друку: 22.05.19; опубліковано: 28.06.19

Резюме. Визначено фітосанітарний стан зелених насаджень, які формують дендрофлору міста. У результаті інвентаризації зафіксовано, що 80,0\% дерев та кущів характеризуються ростом, котрий загалом відповідає нормі, і мають близько 20-25\% нежиттєздатної поверхні. Дерева з ослабленим ростом становлять 13,1 \% від загальної кількості рослин. В озелененні міста найменша кількість $(0,8 \%)$ мертвих та повністю всохлих дерев, а 2,5\% - iз пригніченим ростом, приріст поточного року яких практично відсутній. Дерева без пригніченого росту з повноцінною листовою поверхнею становлять лише 3,6 \%. Досліджено поширення основних фітопатогенних організмів та грибкових захворювань.

Значну увагу приділено хворобам листків, серед яких найбільш притаманні для деревних видів міста Луцька такі, як борошниста роса, крайовий некроз, бура плямистість, чорна плямистість листків клена, іржа груші, чернь листків. Із дереворуйнівних грибів виявлено значне поширення трутовиків справжнього, несправжнього, лускатого та сірчано-жовтого.

Наведено характеристику динаміки поширення Cameraria ohridella Deschka \& Dimic та Viscum album L., ураховуючи дані попередніх років.

Відповідно до результатів дослідження найбільш поширених ентомошкідників, виокремлено ушкодження Pulvinaria betulae L., Aphis pomi Deg., Myzus cerasi F., Disaphis reaumuri Mordv., Drepanosiphum platanoidis Schrank, Eucalipterus tiliae L.

Ключові слова: фітосанітарний стан, Луцьк, озеленення, хвороби листків, ентомошкідники, життєздатність рослин, дереворуйнівні гриби, омела біла.

\section{Phytosanitary Condition of Green Plantations in Urban Landscaping of Lutsk}

\section{Mariia Shepeliuk, Yuliia Rybak}

Lesia Ukrainka Eastern European National University, Lutsk, Ukraine Correspondence: shepelyk.maria@gmail.com

\begin{abstract}
The phytosanitary condition of green plantations forming the city dendroflora is determined. As a result of the inventory it has been recorded that $80,0 \%$ of trees and shrubs are characterized by growth which corresponds to the norm generally; they have about $20-25 \%$ of the non-vitable surface. Trees with weakened growth make up $13.1 \%$ of the total number of plants. The planting has smallest number $(0,8 \%)$ of dead and completely dead trees, $2,5 \%$ of trees with depressed growth; their increase during current year is almost absent. Trees without depressed growth with a full leaf surface make up only 3,6\%. The distribution of the main phytopathogenic organisms and fungal diseases is investigated.

The considerable attention is paid to the diseases of leaves, among which the most characteristic for woody types of the Lutsk city are powdery mildew, marginal necrosis, brown spotty, black spotted leaflets of maple, rust pears, black leafs. Regarding wood-destroying mushrooms it was found a significant distribution of trunks: genuine, false, flaky and sulfur-yellow.
\end{abstract}


The characteristics of the propagation dynamics of Cameraria ohridella Deschka \& Dimic and Viscum album L., taking into account the data of previous years, are predicted.

According to the research results of the most common pests, the damages of Pulvinaria betulae L., Aphis pomi Deg., $\quad$ Myzus cerasi F., Disaphis reaumuri Mordv., Drepanosiphum platanoidis Schrank, Eucalipterus tiliae $\mathrm{L}$ are specified.

Key words: phytosanitary condition, Lutsk, planting, leaf diseases, pests, viability of plants, wood-decay mushrooms, mistletoe white.

\section{Вступ}

Зелені насадження в місті створюють своєрідні екосистеми, які перебувають у безперервному процесі адаптації до динамічних міських особливостей. У зв'язку зі зростаючою концентрацією населення міста, що зумовлює наростання антропічних навантажень на природні та паркові території, міські насадження потребують регулярного й стабільного догляду та уваги з боку людини $[1,2]$.

Основні чинники, які в цілому впливають на ріст і розвиток рослин у місті, можна розділити на три категорії: фізичні, хімічні та антропогенні [3]. Фізичні чинники впливу мають здатність проявлятись у грунтовокліматичних характеристиках об'єктів, умісті основних елементів живлення, щільності грунтів, кислотності водного режиму тощо [2]. Хімічні викликані, зі свого боку, особливостями конкретного міського середовища: задимленістю, загазованістю й запиленістю, змінами режимів освітлення та температури. Антропогенні фактори пов'язані $з$ порушенням агротехніки висаджування й догляду за насадженнями. Окрім того, рослини в місті часто страждають від механічних пошкоджень та рекреаційного тиску [4].

Як результат, на міські зелені насадження впливає велика кількість урбогенних чинників, унаслідок сукупної дії яких відбувається ослаблення росту деревних рослин, що, зі свого боку, спричиняє їх пошкодження різноманітними шкідниками та ураження хворобами $[5,6,7]$.

\section{Матеріали й методи дослідження}

Система зелених насаджень міста Луцька за планувальною структурою $є$ комбінованою й представлена об'єктами спеціального, загального та обмеженого користування. Iзпоміж насаджень обмеженого користування визначено фітосанітарний стан деревних рослин лише Луцької загальноосвітньої школи № 15. Такий дослідний об'єкт обрано, ураховуючи цінність дендрарію, що розміщений у межах території цього закладу.

Серед насаджень загального користування схарактеризовано провідні рекреаційні зони Розділ I. Ботаніка міста: Центральний парк культури і відпочинку імені Лесі Українки (далі - ЦПКіВ ім. Лесі Українки, площа - 60 га); Парк ім. 900-річчя Луцька (16 га); Меморіал Вічної Слави (5 га); сквери на вулицях Лесі Українки «Зоряний», Богдана Хмельницького «Святого Миколая» та поблизу залізничного вокзалу на Привокзальному майдані. Проведено інвентаризацію головних площ міста - Театрального й Київського майданів.

Серед насаджень спеціального призначення досліджено вуличні насадження. Із них виокремлено найбільш значні та популярні об'єкти, що розділені на категорії згідно 3 планувальною структурою містобудівної ситуації, а саме: вулиці центральної частини міста (Степана Бандери, Потапова, Винниченка, Привокзальна, Гулака-Артемовського, Ярощука, Некрасова, Шопена, Коперника, Лесі Українки); периферії (Дубнівська, Набережна, Ковельська, Червоного Хреста, Львівська, Володимирська, Стрілецька) й проспектів (Волі, Перемоги, Василя Мойсея, Відродження, Молоді, Грушевського).

Мета дослідження - оцінити фітосанітарний стан насаджень та визначити видовий склад фітопатогенів й ентомошкідників дендрофлори міста Луцька.

$\mathrm{У}$ процесі виконання роботи застосовано загальнонаукові (аналіз, синтез, системний підхід, спостереження, узагальнення); спеціальні (візуальні - визначення загального стану рослин, лісівничо-таксаційні - створення інвентаризаційних відомостей) та математичностатистичні (обробка експериментальних даних за допомогою пакета комп'ютерних програм) методи дослідження.

\section{Результати досліджень й обговорення}

Під час проведення інвентаризації зелених насаджень оцінено їх загальний стан за п'ятибальною шкалою візуальної оцінки С. І. Кузнецова, Ф. М. Левона, Ю. А. Клименка, П. Ф. Пилипчук, М. І. Шумика [8]. Ця методика включала переважно життєздатність рослин, їх здоровий ріст та повноцінність листових поверхонь.

За результатами інвентаризації 80,0 \% дерев i кущів отримали по 4 бали, тобто вони 
Фітосанітарний стан зелених насаджень у міському озелененні Луиька

характеризуються ростом, що загалом відповідає нормі, та мають близько 20-25\% недієвої поверхні. 13,1\% від загальної кількості рослин становлять дерева 3 ослабленим ростом (3 бали). В озелененні міста найменша кількість $(0,8 \%)$ мертвих і повністю всохлих дерев (1 бал). 2 бали отримали 2,5\% дерев iз пригніченим ростом, приріст яких поточного року майже відсутній. Дерева без пригніченого росту 3 повноцінною листовою поверхнею (5 балів) становлять лише 3,6 \% (рис. 1).

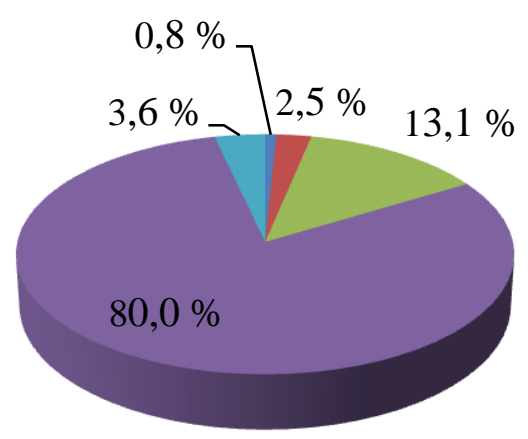

$$
\begin{aligned}
& \text { - } 1 \text { бал } \\
& -2 \text { бали } \\
& -3 \text { бали } \\
& -4 \text { бали } \\
& -5 \text { балів }
\end{aligned}
$$

Рис. 1. Загальна діаграма оцінки життєздатності деревних рослин міста

На зменшення життєздатності деревних рослин у місті Луцьку впливає поширення омели білої (Viscum album L.). Це напівпаразит, який оселяється на надземних частинах дерев та призводить до зниження їх естетичної, фітомеліоративної функцій, спричиняє швидке старіння й відмирання особин.

Наймасивніші осередки поширення омели білої спостерігають на видах родів Populus L., Sorbus L., Salix L., а також усіх плодових, що перебувають у зрілому віці.

На вулицях центральної частини міста зафіксовано поширення Viscum album L. на таких видах, як Sorbus aucuparia L., Malus domestica (Borkh.) Borkh., Sorbus intermedia (Ehrh.) Pers., Fraxinus excelsior L., де загалом є 18 уражених рослин. У насадженнях вулиць периферії - Sorbus aucuparia L., Malus domestica (Borkh.) Borkh. i Fraxinus excelsior L., загалом дев'ять рослин. На проспектах виявлено 11 уражених рослин: Robinia pseudoacacia L., Tilia cordata Mill., Sorbus intermedia (Ehrh.) Pers. та S. aucuparia L. У дендрарії Луцької загальноосвітньої школи № 15 Viscum album L. уражено лише один екземпляр - Aesculus $\times$ carnea Zeyh. У скверах відсутні уражені рослини, а також немає уражених омелою білою дерев на головних площах міста й у Меморіалі Вічної Слави. Натомість значні осередки поширення омели зафіксовано в Центральному парку культури i відпочинку імені Лесі Українки та Парку ім. 900-річчя Луцька.

Результати аналізу поширення омели білої в насадженнях міста Луцька впродовж 20012005 pp. відзначають лише поодиноке ураження представників Tilia cordata Mill., Acer pseudoplatanus L., Sorbus aucuparia L., Betula pendula Roth., Prunus cerasifera Ehrh. і фіксують абсолютну стійкість до ураження напівпаразитом таких видів рослин, як Salix alba L., Acer platanoides L. та A. sacharinum L. [9]. Нині зафіксовано ураження всіх вищенаведених видів у насадженнях різного функціонального призначення. Також відзначимо ураження омелою білою дерев Fraxinus excelsior L. у вуличних і паркових умовах, ураховуючи, що ураження його екземплярів не спостерігали в місті в попередні роки.

Під час інвентаризації та маршрутних обстежень насаджень міста виявлено поширення дереворуйнівних грибів, що спричиняють різноманітні стовбурні гнилі, які відрізняються характером і ступенем руйнування деревини [10]. Це переважно трутовики - справжній, несправжній, лускатий, сірчано-жовтий. Трутовик справжній (Fomes fomentarius (L. ex Fr.) Gill.) трапляється на Populus nigra L., P. alba L., Betula pendula Roth., Acer negundo L., Salix matsudana L. (загалом 9 шт. у ЦПКіВ ім. Лесі Українки та Парку ім. 900-річчя Луцька), на Aesculus hippocastanum L. i Tilia cordata Mill. у проспектах по дві уражені рослини (рис. 2).

Трутовик несправжній (Phellinus igniarius (L. ex Fr.) Quel.) паразитує на Betula pendula Roth., Alnus glutinosa (L.) Gaerth., Salix alba L., Acer negundo L., Fraxinus excelsior L.,

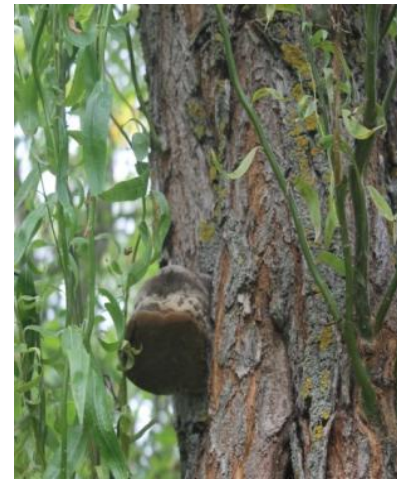

$a$

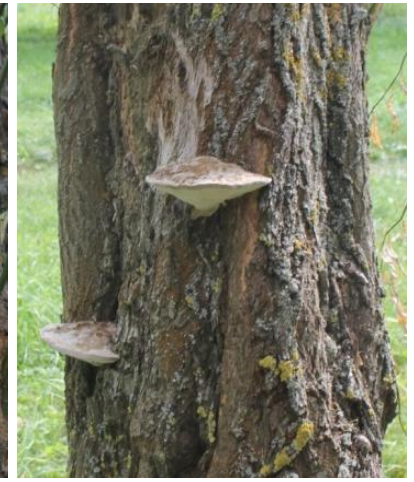

$\sigma$
Рис. 2. Уражені стовбури Salix matsudana Koidz. у Центральному парку культури і відпочинку імені Лесі Українки:

$a$ - трутовиком справжнім; б- трутовиком плоским. 
Carpinus betulus L., Fagus sylvatica L. і видах Populus nigra L. (вулиці периферії міста 6 уражених дерев, парки - 4 шт.).

Трутовик лускатий (Polyporus squamosus (Huds.) Fr.) уражає Ulmus laevis Pall., Acer negundo L., Quercus robur L., Fraxinus excelsior L. та види плодових дерев (зокрема Malus domestica (Borkh.) Borkh.) (парки - 3 шт., вулиці центральної частини міста - 2).

Сірчано-жовтий трутовик (Laetiporus sulphureus (Bull.) Bond. Et Sing) - викликає червоно-буру ядрову гниль стовбурів дерев родів Quercus L., Fagus L., Fraxinus L., Acer L., Salix L., а також голонасінних - Larix Mill. i Picea A. Dietr (парки - 4 шт.).

Серед хвороб листків найтиповішими для деревних видів міста Луцька є борошниста роса клена (збудник гриб Uncinula aceris Sacc.), борошниста роса бузку (Mikrosphaera syringae) й дуба (Microsphaera alphitoides Griff, et Maubl.). Характеризуються утворенням на уражених частинах рослин (листках, стеблах, плодах) грибниці у вигляді білих або сіруватих борошнистих нальотів.

Причому уражені майже всі види кленів міста: на Київському майдані Acer platanoides 'Globosum' (14 шт., або 28,5\% від кількості всіх листяних дерев майдану); на Театральному - Syringa vulgaris L. (2 шт.) та Acer platanoides 'Globosum' (4 шт.); на Меморіалі Вічної Слави - Quercus robur L. (3 шт.), Quercus rubra L. (23 шт.); у ЦПКіВ імені Лесі Українки - Acer platanoides 'Globosum' (1 шт.), Syringa vulgaris L. (5 шт.). У сквері «Зоряний» - Syringa vulgaris L. (3 шт.), на просп. Волі - Acer platanoides 'Globosum' (50 шт.), на вулиці Лесі Українки - Acer platanoides 'Globosum' (1 шт.), а також екземпляри Acer pseudoplatanus 'Atropurpureum' на майдані Грушевського.

Загальна кількість уражених рослин значно більша. Такі дані $€$ результатом того, що грибницю на листках за зовнішніми ознаками можна побачити лише 3 кінця літа. До того моменту зафіксувати візуально при інвентаризації насаджень - складно.

Розповсюдженим явищем $є$ крайовий некроз листків у видів родів Tilia L., Aesculus L. Cerasus Mill. та Acer L. Це неінфекційна хвороба, яка викликана зазвичай несприятливими умовами зовнішнього середовища, посухою, перезволоженням, переущільненням чи забрудненням грунту або ж повітря $[11,12]$. Аналогічні симптоми можуть бути спричинені й розвитком дереворуйнівних гнилей, що викликаються трутовиками. Некротичні ділянки розпочинаються, зазвичай, із країв листка та можуть займати значну його частину. Листки при цьому виглядають обпаленими й деформуються. Уражені рослини наявні в міських вуличних насадженнях, де зосереджено велику кількість автотранспорту. Найбільше уражених екземплярів зафіксовано на вулицях периферії міста (12 шт.) у Tilia cordata Mill., на проспектах (7 шт.) - Aesculus hippocastanum L. i Cerasus vulgaris L., на вулицях центральної частини міста - лише два представники (Acer pseudoplatanus L.). У парку крайовий некроз виявили лише в одного Acer platanoides 'Globosum'.

Відзначено також крайовий некроз листків Cercidiphyllum japonicum Siebold \& Zucc. у дендрарії Луцької загальноосвітньої школи № 15, що може бути зумовлено переущільненням і бідністю грунту, оскільки зростає на подвір'ї школи та піддається постійному рекреаційному навантаженню.

На листках деяких представників Aesculus hippocastanum L. спостерігають «опіки», які теж можуть бути спричинені несприятливими грунтово-кліматичними умовами. Такі екземпляри трапляються в насадженнях вулиць периферії (6 шт.), а на проспектах зафіксовано деформовані листки Tilia cordata Mill. (2 шт).

Також серед уражень фітопатогенними мікроорганізмами простежено буру плямистість листків різних видів. Так, на вулицях центральної частини міста зафіксовано по три уражені рослини Acer negundo L. i Juglans regia L. Ознаками бурої плямистості на Juglans regia L. $є$ поява на листках округлих плям бурого забарвлення. Вона найчастіше виникає в період затяжних дощів, коли в грунті накопичується занадто багато вологи. Уражені листки значно швидше опадають. Збудником бурої плямистості кленів є Mycocentrospora acerina (R. Hartig) Deighton. На уражених листках спочатку з'являються дрібні темночервоні плями, які 3 часом збільшуються й поступово захоплюють цілий лист.

На периферії міста буру плямистість виявлено у Fraxinus excelsior L. (2 шт.), збудником якої виступає Phyllosticta fraxini Ellis \& G. Martin. Унаслідок ураження на листках ясенів 3'являються округлі коричневі плями, оточені темно-червоною облямівкою. Їх діаметр варіює від 5 до 10 мм. Це викликає передчасне обпадання листків та всихання пагонів.

Некротичні плями бурої плямистості зафіксовано в Tilia cordata Mill. (5 шт.) на проспектах. Збудником є Mycosphaerella millegrana (Cooke) J. Schröt. На листках iз 
Фітосанітарний стан зелених насаджень у міському озелененні Луиька

початку липня з'являються чорно-бурі плями неправильної або округлої форми зі світлосірим центром і діаметром до 4 мм. При сильному ураженні вони майже повністю покривають листкову пластинку.

Через розвиток гриба Pestalotiopsis funereoides Steyaert відзначено побуріння хвої в представників Thuja plicata Donn ex D. Don., Platycladus orientalis (L.) Franco в ЦПКiB ім. Лесі Українки.

Чорна плямистість листків клена (збудник гриб Rhytisma acerinum (Pers.) Fr.) уражає всі види Acer L. та різко знижує їх декоративність. Поширена в насадженнях периферії міста i в ЦПКіВ ім. Лесі Українки на представниках Acer platanoides L. та Acer pseudoplatanus L. (8 уражених рослин).

У вуличних посадках Tilia cordata Mill. на листках i пагонах виявлено падь (медяну «росу»), яка є результатом виділень попелиць, котрі живляться на органах рослин.

Унаслідок покриття паддю листки стають липкими й на них потрапляють токсини, пил, спори різних грибків та мікроорганізмів, які починають там розмножуватись [13]. Після цього падь темніє й змінюється іiі хімічний склад. Такі процеси призводять до утворення черні, що належить до інфекційних хвороб листків. Вона являє собою чорну або сірочорну плівку, що викликана сапротрофними грибами $[7,14]$.

Чернь зафіксовано в усіх групах вуличних насаджень, зокрема 11 уражених рослин на проспектах, на вулицях центральної частини міста -6 шт., на вулицях периферії - 3 шт.

Іржу груші (збудник - Gymnosporangium sabinae Dicks.) виявлено в насадженнях обмеженого та загального користування. Уражує види роду Pyrus L., а провідним господарем $є$ Juniperus communis L. i J. virginiana L. Перші ознаки іржі на листках з'являються в кінці квітня - на початку травня у вигляді дрібних округлих зелено-жовтих плям діаметром 0,5 мм. Вони постійно збільшуються в розмірі й здувається уражена частина листка, із нижньої сторони якого утворюються еції, де формуються еціоспори. Еціоспори розсіюються вітром i, потрапивши на хвою ялівців, за наявності вологи, проростають, утворюючи міцелій. Зафіксовано ураження листків Pyrus communis L. у Парку ім. 900-річчя Луцька (2 шт.) та на вулицях центральної частини міста (3 шт.) (рис. 3).

Серед ентомошкідників зелених насаджень найпоширенішими $є$ березова псевдощитівка (Pulvinaria betulae L.), яка уражає рослини

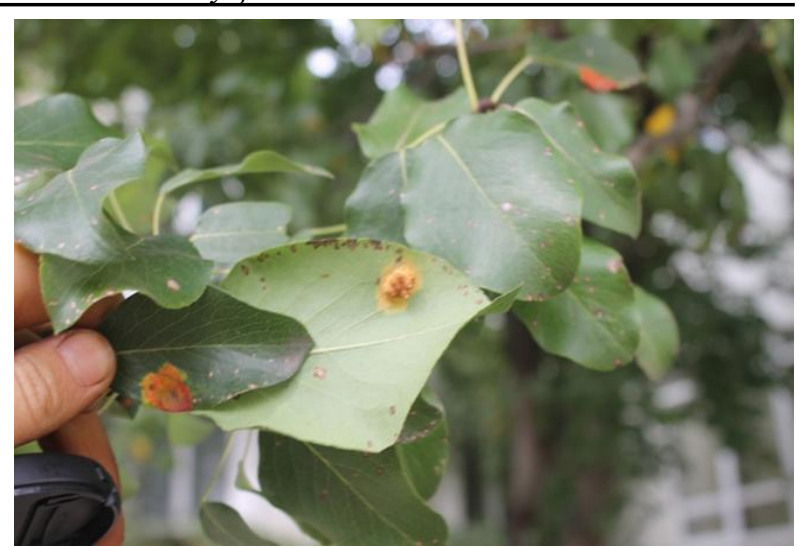

Рис. 3. Іржа груші на листках у Парку ім. 900-річчя Луцьька

Betula pendula Roth. вулиць периферії міста; попелиці: зелена яблунева (Aphis pomi Deg.) уражає Malus domestica(Borkh.) Borkh., Pyrus communis L., Crataegus monogyna Jacq., Sorbus aucuparia L., Cotoneaster lucidus Schltdl., вишнева (Myzus cerasi F.), що пошкоджує Cerasus avium (L.) Moench i Prunus cerasus L.; попелиця-листовійка (Disaphis reaumuri Mordv.), котра уражає Pyrus communis L. Інтенсивний розвиток та ураження дерев Tilia на проспектах відзначено липовою попелицею (Eucalipterus tiliae L.). Великою кленовою попелицею (Drepanosiphum platanoidis Schrank) ушкоджено Acer platanoides L. та A. pseudoplatanus L. Попелиці живляться на верхівках молодих пагонів і листках. Пошкоджені листки зморщуються, буріють та згодом засихають (рис. 4).

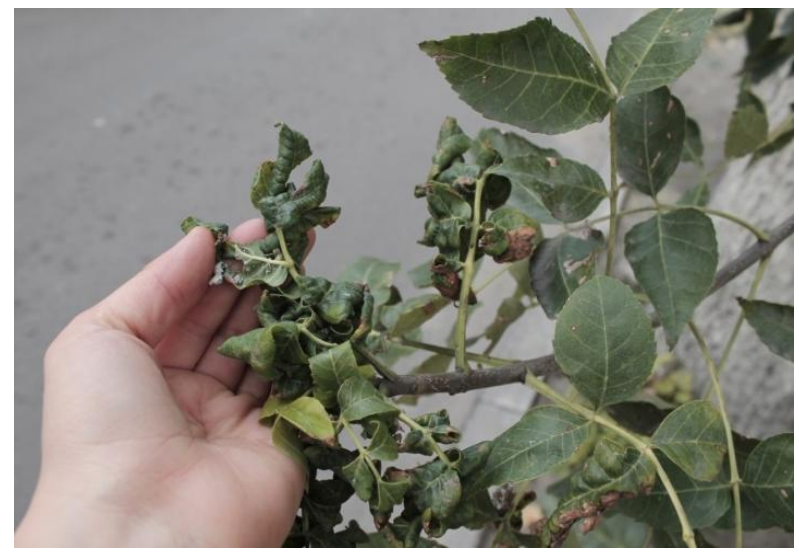

Рис. 4. Деформовані листки внаслідок ураження попелицями на вул. Степана Бандери

Для вуличних насаджень притаманні ураження рослин роду Tilia липовою галицею (Didymomyia tiliacea Bremi.). У багатьох видів (Robinia pseudoacacia L., Acer saccharinum L., A. platanoides L., A. pseudoplatanus L., Tilia cordata Mill., T.platyphyllos Scop., Quercus robur L., $Q$. rubra L.) листкові пластинки містять паразитичні новоутворення - 
гали (рис. 5), викликані, залежно від особливостей ушкодження, різними комахами наприклад галицями, горіхотвірками, пильщиками, листоблішками, галовими кліщиками тощо.

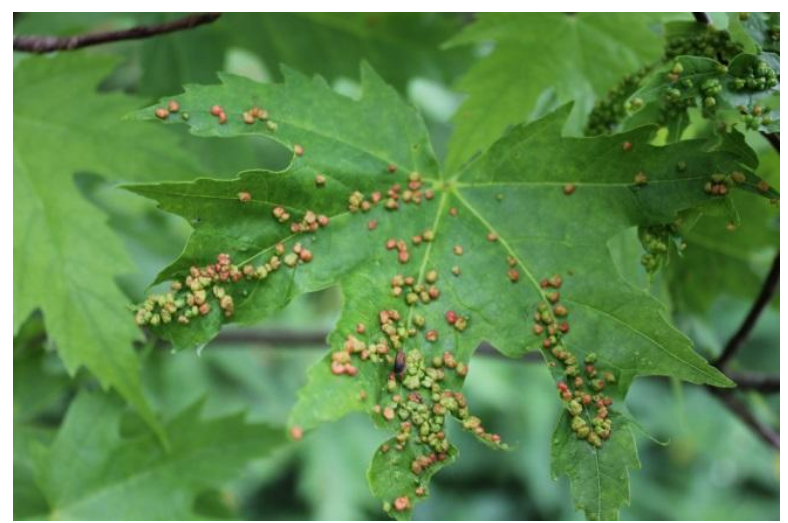

Рис. 5. Гали на листках Acer platanoides $L$. у Центральному парку культури $і$ відпочинку імені Лесі Українки

Найпопулярнішими кліщиками, розповсюдженість яких фактично сягає всіх груп насаджень, є липовий галовий (Eriophyes tiliae L.), крайовий (Eriophyes tetratrichus Nal), звичайний павутинний (Tetranychus urticae Koch.), липовий павутинний (Schizotetranychus tiliarum Herm.) i червоний яблуневий (Metatetranychus ulmi Koch.).

Великий спектр видового різноманіття насаджень вулиць периферії вражає кленова стрільчатка (Acronicta aceris L.).

Відзначимо ураження каштановою мінуючою міллю (Cameraria ohridella Deschka \& Dimic), що практично знижує декоративність ycix Aesculus hippocastanum L. Як засвідчили дослідження, перші ознаки пошкодження листя каштанів окремими колоніями молі в Луцьку зафіксовано в 1998-1999 pp. [15]. Значне поширення, при якому некротичні плями займали вже $100 \%$ листкової пластинки, відзначені у 2004-2005 pp., проте на той момент - лише у вуличних посадках. На сучасному етапі спостерігаємо таке ж поширення мінуючої молі у скверах та в паркових умовах.

\section{Висновки}

На зелені насадження міста Луцька впливає велика кількість урбогенних чинників, унаслідок сукупної дії яких відбувається ослаблення росту та розвитку деревних рослин, що, зі свого боку, спричиняє їх пошкодження різноманітними шкідниками й ураження збудниками хвороб.
Як результат дослідження фітосанітарного стану, наймасивніші осередки поширення омели білої спостерігаємо на рослинах родів Populus L., Sorbus L., Salix L., а також усіх плодових, що перебувають у зрілому віці.

Виявлено поширення дереворуйнівних грибів, що спричиняють різноманітні стовбурні гнилі, які відрізняються характером і ступенем руйнування деревини. Це переважно трутовики - справжній, несправжній, лускатий, сірчаножовтий.

Серед хвороб листків найтиповішими для деревних рослин міста Луцька виявилися борошниста роса клена, борошниста роса бузку та дуба; крайовий некроз листків у видів родів Tilia L., Aesculus L. Cerasus Mill. i Acer L.; бура плямистість листків різних видів; чорна плямистість листків клена; іржа груші; чернь листків.

Серед ентомошкідників зелених насаджень найпоширеніші березова псевдощитівка (Pulvinaria betulae L.), яка уражує рослини Betula pendula Roth. вулиць периферії міста; попелиці - зелена яблунева (Aphis pomi Deg.), уражує Malus domestica(Borkh.) Borkh., Pyrus communis L., Crataegus monogyna Jacq., Sorbus aucuparia L., Cotoneaster lucidus Schltdl.; вишнева (Myzus cerasi F.) - пошкоджує Cerasus avium (L.) Moench i Prunus cerasus L.; попелиця-листовійка (Disaphis reaumuri Mordv.) - уражає Pyrus communis L. Інтенсивний розвиток й ураження дерев Tilia Mill. на проспектах відзначено липовою попелицею (Eucalipterus tiliae L.). Великою кленовою попелицею (Drepanosiphum platanoidis Schrank) ушкоджені Acer platanoides L. та A. pseudoplatanus L. Каштанова мінуюча міль (Cameraria ohridella Deschka \& Dimic) знижує декоративність майже всіх представників Aesculus hippocastanum L.

\section{Література}

1. Ежов, О.Н. Вредители и болезни городских зеленых насаждений архангельского промышленного узла. Лесной журнал; 2008, № 3, с 46-50.

2. Яловенко, А. С. Життєвий стан деревних насаджень парку ім. Т. Г. Шевченка м. Запоріжжя. Вісник Дніпропетровського університету. Біологія. Екологія; 2011, Вип. № 1, т. 1, с 143-149.

3. Beisman, H. Measuring the effect of air pollution on the environment with standardized methods. Int. J. Hyg. Enviton. Helth; 2006, Vol. 209, p 207-208.

4. Курницька, М. П. Життєвість міських зелених насаджень. Науковий вісник УДЛУ; 2003, Вип. 13.5, c 308-311.

5. Билай, В. И.; Гвоздяк, Р. И.; Скрипаль, И. Г. 

Микроорганизмы - возбудители болезней
растений; Киев, 1988, 552 с.
6. Ковалевський, С. Б.; Шепелюк, М. О. Основні
чинники пошкодження та ураження деревних видів зелених насаджень міста Луцьк. Перспективи розвитку лісового та садово-паркового господарства: Всеукр. наук.-практ. конф.; Умань, 14 груд. 2016 р.: тези доп., 2016, с 133-134.

7. Цилюрик, А. В.; Шевченко, С. В. Лісова фітопатологія; Київ, 2008, 464 с.

8. Кузнєцов, С. І.; Левон, Ф. М.; Пилипчук, В. Ф.; Шумик, М. І. Екологічні передумови оптимізації вуличних насаджень Києва. Питання біоіндикаціі та екологї; Запоріжжя, 1998, № 3. с 57-64.

9. Ковальчук, Н. П. Еколого-біологічні проблеми зелених насаджень м. Луцька: монографія; Луцький нац. техн. ун-т; РВВ ЛНТУ: Луцьк, 2011, 187 с.

10. Клюшник, П. И. Определитедь дереворазрушающих грибов; Москва, 1957, 140 с.

11. Мелехова, П. О.; Егорова, Е. И.
Биологический контроль окружающей среды: биоиндикация и биотестирование: учеб. пособие для студ. высш. учеб. Заведений; Москва, 2007, $288 \mathrm{c}$.

12. Стольберг, Ф. В. Екологія міста; Лібра: Київ, $2000,464 \mathrm{c}$.

13. Звіт про пророблену роботу по уточненню радіаційної обстановки в місті Луцьку Волинськой області в період з 10.04. по 30.09.1991 року; Волин. центр гідрометеорології: Луцьк, 1991, 22 с.

14. Олексійченко, Н. О.; Совакова, М. О.; Соваков, О. В.; Китаєв, О. І.; Слюсар, С. I. Tilia L. y насадженнях м. Києва: монографія; Київ, 2013, $245 \mathrm{c}$.

15. Іванців, В. В.; Іванців, О. Я. Екологічні чинники погіршення стану деревних насаджень міста Луцька. Природа Західного Полісся та прилеглих територій; Східноєвроп. нац. ун-т ім. Лесі Українки: Луцьк, 2014, № 11, с 231-235. 